\title{
Paving Way for Road Infrastructure Development in Public Private Partnership Emerging Economies: Lessons from Global Experiences and Policy Practices
}

\author{
Jude Thaddeo Mugarura $^{1 *} \quad$ Zwelinzima Ndevu $^{2} \quad$ Festo Nyende Tusubira $^{3}$ \\ 1.Department of Marketing and Management, College of Business and Management Sciences, Makerere \\ University, P.O.Box 7062, Kampala, Uganda \\ 2.School of Public Leadership, Faculty of Economic and Management sciences, \\ Stellenbosch University, P.O. Box 7602, Private Bag XI. Matieland, South Africa \\ 3. Department of Accounting and Finance, College of Business and Management Sciences, Makerere University, \\ P.O.Box 7062, Kampala, Uganda
}

\begin{abstract}
Mismanagement of financing, tolling and project processes have been at the centre of the slow development of road infrastructure. Using a global outlook approach, this study synthesizes the public private partnership (PPP) financial challenges, tolling practices and PPP roads project experiences. Case studies were purposively selected to identify successes, failures, and reasons why such happened, as well as measures that have been taken to improve the PPP operating environment across the globe. This paper provides broad lessons upon which PPP emerging economies, especially those in Africa can improve road infrastructure for sustainable development.
\end{abstract}

Keywords: road infrastructure, financial challenges, PPP road cases, tolling, lessons, PPP emerging economies

DOI: $10.7176 / \mathrm{PPAR} / 10-10-07$

Publication date:October $31^{\text {st }} 2020$

\section{Introduction}

Road infrastructure is critical for sustainable development across the World, and in particular, carries over $90 \%$ of the total freight and passenger movements in Africa (Biau, Dahou \& Homma 2008). Road network is therefore the primary link between urban and rural areas to boost trade, industrialisation, agricultural productivity, and access to social services. However, Africa remains the least productive and competitive continent of the world (Ondiege, Moyo \& Verdier-chouchane 2013), largely because of inadequate and underdeveloped road infrastructure. For instance, only 34\% of Africa's population have access to roads compared to a 50\% population for other developing continents (Ondiege et al. 2013), and out of the 2 million kilometres of Africa's roads only 27.6\% are paved (against 43\% for South Asia) (Biau et al. 2008).

The poor state of the roads increases operational costs and production losses. For instance, a survey conducted in the Democratic Republic of Congo showed that transportation costs were on average two times greater on earthsurfaced roads than on paved roads (Biau et al. 2008), while, in Ghana, about $15-20 \%$ of the fruits delivered by out-growers on feeder roads are rejected by nucleus farms due to in transit caused damages (Ferrantino 2009). The underdevelopment of the road network has also resulted in severe traffic congestion and accidents. According to Ondiege et al. (2013) traffic congestion is estimated to cause direct loss of time and productivity at an annual cost of US\$19 billion in Lagos, US\$0.89 billion in Dar es Salaam, and US\$0.57 billion in Nairobi. In 2016, the world health organisation (WHO) estimated that 1.2 million people die and 50 million are seriously injured each year in road traffic accidents. For example, Uganda has one of the worst road safety records in Sub-Saharan Africa, with an average rate of 45 fatalities per 10,000 vehicles (Ondiege et al. 2013).

In addition, accessibility to the road network is uneven, with rural areas largely underserved (Ondiege et al. 2013), since 70\% of Sub-Saharan Africa's (SSA) rural population lives more than $2 \mathrm{~km}$ away from an all-weather road (Wohl 2009). For example, in Chad, during the rainy season, teachers and students cannot get to schools and the sick have difficulty reaching the limited medical facilities because of poor quality roads (Jabara 2009). More so, when road infrastructure is not user friendly, drivers tend to take alternative routes that often require longer travel times (Wohl 2009), something that not only creates delivery delays but also increases overall transport costs. The prolonged delivery problem is further exacerbated by the very low maximum driving speed, as vehicles slow down to avoid potholes or navigate uneven terrain (Wohl, 2009).

Given Africa's road infrastructure development challenges, and while PPPs would fundamentally introduce innovative sources of funding and better management competencies for public investments, developing countries' experiences seem to suggest that PPPs have had vast financial and other management challenges to have a significant improvement on road infrastructure. This study therefore synthesizes the global PPP financial challenges, and the tolling practices and PPP roads project experiences, to subsequently provide lessons upon which PPP emerging economies, especially in Africa can improve road infrastructure for sustainable development. 


\section{Methodology}

Case study approach was employed to evaluate the impact of the global financial crisis (GFC) on PPP investments, the role of road tolls in infrastructure development, and to analyse PPP road practices through a review of relevant scholarly documents. Financing issues based on the 2008 GFC, tolling practices, and PPP road project cases come from four continents, but with a few differences across countries. Notwithstanding the fact that GFCs provide a better representation of financial hurdles in an international space, the 2008 global financial crisis was preferred for use because unlike other global financial crises (that is, the Asian of 1997, the Dotcom bubble of 2002), the 2008 global financial crisis sets a new and unique trend, where PPP investment grows steadily amidst stiff global financial challenges, as well as having the highest number of PPP projects during the overall period (See World Bank Group 2016).

Furthermore, tolling becomes critical to this study because it works as a means through which Special Purpose Vehicle (SPV) companies recoup their money, as well as being an instrument of transport demand management. While PPP road projects were of essence to this study because roads carry over $90 \%$ of passenger and cargo, and are annually allocated the highest investment financing compared to other sectors/subsectors in Africa.

Cases studies come from countries of different continents in order to create a more globalized and balanced stance of PPP lessons drawn from extant studies for improving road infrastructure in Africa as well as other PPP emerging economies in the world. Case studies were found relevant for this study because they support several ways of analysing and explaining data in order to provide more solid generalizable claims (Mason 2002). Documents used in the study were first, purposively selected based on their ability to provide key learning points of improving PPP operations and systems. Subsequently, theoretical sampling was employed to avoid the use of documents or case studies that had more or less the same issues. Finally, only documents/cases that elaborately reported on successes and failures as well as conditions for the occurrence of both situations, and measures/recommendations taken for improvement had to be used.

\section{The 2008 global financial crisis as a proxy for Public private partnership financial challenges, their impact and management}

Prior to the 2008 global financial crisis, PPPs relied on debt financing from banks and bond financing (from Project companies) that was insured through monoline "wrapped" bonds (Loxley 2012). Although these two financing mechanisms had revived PPP investment, they were later suffocated by the collapse of the monoline insurance "wrapped" bond markets, and a sharp decline of housing markets and banking institutions in 2008 (Connolly \& Wall 2011).

\subsection{Financial challenges and their effects on public private partnership investment}

The 2008 GFC caused a hike in interest rates, made credit scarce, exchange rates drastically depreciated and domestic demand for PPP services on user fees arrangement was either low or resisted. During this time many banking, pension fund and insurance institutions either pulled out or ran out of business, and a few that remained in operation have since then redesigned and tightened their financing incentives for investors. As such the GFC saw governments experience reductions in revenue collections, foreign and domestic financing, and high unemployment coupled with a drastic drop in individual incomes; and the private sector's capacity to sustain PPP investment was hanging in balance. Provided in table 1, are Country specific effects, where South Africa represents Africa, Canada for North America, and Korea for Asia.

Table 1. Effects of the Global Financial Crisis on Public Private Partnerships in Canada, Korea and South Africa

\section{Canada}

$>$ Difficult to secure long-term and foreign financing as foreign banks withdrew from the domestic market

$>$ Lenders were no longer willing to take up project and refinancing risks because the Canadian dollar was beginning to be unstable

$>$ Formerly approved PPP projects were now being implemented under the public procurement option

$>$ Difficulty reaching final agreements because of risk sharing challenges during negotiation

Lack of capacity by credit market to handle large projects that were over $\$ 500$ million

South Africa

$>$ Reduced profitability and returns on equity

$>$ Increased risk aversion of government

$>$ lower access to financing

$>$ lower demand for facilities with a usage charge

$>\quad$ Reduction in PPP investment

Modified from Burger et al. (2009)

\section{Korea}

$>\quad$ In 2009 , a $10 \%$ reduction in annual port traffic was registered

$>$ Reduced profitability for PPP projects at operation stage

$>$ Delay to implement projects because of lack of funding and prolonged negotiations as parties were hesitant to assume risks

$>\quad$ By $2008,30 \%$ of the planned PPP projects were never implemented Increased speculations of a further decline in future private investment Increased interest rates and reduced accessibility to project financing 
Amidst such stiff economic challenges, governments were expected to come up with measures for bailing out and supporting private sector financial recovery, protecting citizens against declining incomes (Burger et al. 2009), as well as ensuring that PPP projects continued to be executed successfully against all odds.

\subsection{Management of the 2008 global financial crisis negative impact on PPP performance}

Several measures have been suggested by scholars, and others implemented by countries in ensuring PPPs continue to excel amidst turbulent financial times.

\subsubsection{Generic measures suggested by scholars}

The European Expertise Centre-EPEC (2009) recommended the use of up-front and forward government payments, and an increase in multilateral lending. Up-front and forward payments are common with availability and revenuebased projects, where up-front payments are used in favour of the private sector when the private sector is more financially constrained than the public sector, and the reverse is true for forward payments. Turning to multilateral lending, multilateral institutions can either provide third party guarantees (such as letters of credit) or directly fund PPP projects. A practical example is the European Investment Bank, which introduced a " $€ 1$ billion Loan guarantee instrument for Trans-European Transport Network projects in 2008, and also temporarily expanded its lending capacity by $40 \%$ between 2009 and 2010 in order to address GFC problem in Europe" (Loxley 2012).

Burger et al. (2009) suggested measures of reducing PPP vulnerabilities prior to and during financial crises to include;

$>$ Robust public investment planning based on project prioritization, future financial implications, and benchmarking with international experiences;

$>$ Adequate distribution of risks between the government and the private sector;

$>$ Sound and detailed legal frameworks, which can provide assurance to the private sector that contracts will be honoured by the public sector;

$>$ Regulations limiting aggregate government risk exposure, which should be consistent with existing fiscal frameworks;

$>$ Building the capacity of public entities to manage risks, and improve their reputation by minimising political and regulatory risks;

$>$ Financial transparency through comprehensive disclosure of PPP risks and liabilities in fiscal accounts to mitigate against bypassing expenditure controls or to avoid securing private financing against expensive contractual obligations;

$>$ Providing step-in rights to government to either re-tender the project or take over project operation in case of contractor failure;

$>$ Contingent measures. These are temporary measures subject to withdrawal the moment the economy or the private sector recover from the shock. Such measures include debt-equity switch, government financing, interest rate and output subsidies, and revenue enhancements.

3.2.2 Country specific measures that have been implemented

Although countries across the globe responded in one way or the other to the GFC, this study only focusses on interventions that have been taken by the UK and Ireland representing Europe, and Canada and Korea for North America and Asia respectively.

\section{The United Kingdom}

In 2009, the UK government established the Treasury Infrastructure Funding Unit (TIFU), whose sole purpose was to execute the co-lending strategy in order to tackle the banking liquidity problem that PPP projects and private sector actors in particular were experiencing (Svigelj \& Hrovatin 2013; Jennett 2010). TIFU is a government funding facility within the HM Treasury, which lends directly to PPP projects when the private sector cannot secure enough funding from commercial banks to complete projects on time. Although TIFU lends on "exactly same terms as commercial banks", it never competes with private sector funders for borrowers, because it "acts as a lender of last resort" (EPEC 2009; Loxley 2012). The financing role played by TIFU has restored private sector confidence, and has also enabled more PFI projects to be completed on time. For instance, in 2009 TIFU extended a $£ 120$ loan assistance to the Manchester Waste PFI project, and in 2010 alone, 32 PFI deals valued at $£ 4.6$ billion reached closure (Loxley 2012).

\section{Canada}

The PPP Canada Corporation was established in 2008 with a PPP fund of $\$ 1.2$ billion to develop private market and supplement private sector financing (Burger et al. 2009). The PPP fund provides loans and loan guarantees, and offers non-repayable and repayable financial contributions (Loxley 2012; Svigelj \& Hrovatin 2013). Other Government funding facilities that were started because of the GFC by which PPP projects benefited include the \$8 billion Building Canada Fund, and the \$2.1 billion Gateway and Border Crossing Fund (Loxley, 2012).

Furthermore, the government of Canada got committed to ensuring that provinces and municipals develop their own PPP markets, institutions and programs. For instance, the City of Ottawa established a PPP office, while Alberta province's 2008 budget set aside \$6 million as alternative financing for capital projects (Burger et al. 2009). 
In British Columbia, “milestone payments, co-financing, funding competitions, short-term financing, foreign exchange risk protections, and sharing of co-financing risks for some projects were introduced". In addition, rather than the common $90 \%$ debt and 10\% equity contribution, with the "Fort St. John Hospital and Residential care and Royal Jubilee Hospital projects, equity contribution was increased to 20\% for contractors" (Loxley 2012). On the other hand, in Ontario province, procurement procedures were strengthened. For example, "a two-stage bidding method was introduced, where the financial proposals are submitted and evaluated before technical proposals. In addition, the bidders are required to provide evidence relating to stability of their financial proposals, and to confirm their ability to reach financial closure regardless of future credit market disruptions by providing required securities" (Loxley 2012).

Korea

According to Burger et al. (2009) and Svigelj \& Hrovatin (2013), the government of Korea introduced fiscal interventions, which included:

$>$ Lower equity capital requirements on concessionaires (5-10\%);

$>$ A higher ceiling on guarantees $(50 \%)$ is provided by the Infrastructure Credit Guarantee Fund, specifically for large-scale projects;

$>$ Help in changing equity investors for some projects;

$>$ Compensation for the preparation of proposals to encourage more vigorous competition during bidding;

$>$ Sharing of interest rate risks with concessionaires;

$>$ Compensation for excess changes in base interest rates through the grading of risks at the time of the concession agreement; and

Ireland

Shorter periods for readjusting benchmark bond yields.

Prior to the GFC, PPP road projects were based on revenue based contracts, which required road users to pay toll fees. After the GFC explosion of 2008, the government made a change in policy. Currently, all the new roads being constructed in Ireland are contracted on availability-based schemes rather than the previous tolled systems (Reeves \& Palcic 2017). This implies that demand risks are now being shared between government and private actors, unlike the tolled road systems which almost transferred all the demand and traffic risks to the private sector. As a safe guard measure though, the government should pay a fixed fee per unit on condition that the private entity complies with the performance and availability requirements (Reeves \& Palcic 2017).

Although the focus of discussion has been limited to four countries, similar measures have been applied elsewhere. For instance, like Canada and UK, government PPP Fund facilities are also active in the USA, and the availability-based contracts for road PPP projects being used by Ireland have also taken root in Spain, Portugal and the USA.

\section{Tolling for road infrastructure development}

With the prevailing revenue gaps from excise duty fuel charges, governments across the world have introduced several supplementary financing mechanisms such as tolling, motor vehicle licencing and inspections, and ancillary revenues to meet the road infrastructure development needs. Tolling, in particular is not only being used as a way of recouping the costs of road construction, operation and maintenance but also as an effective means of managing road usage.

\subsection{Tolling as an instrument for road infrastructure financing}

On most projects, payment to the private contractor is not effected before, during and immediately after construction, but during the operation and maintenance of the road facility. The commonly used financing mechanisms in meeting private sector payment demands are the user pay principle (hard/real tolls) and shadow tolls. The user pay principle supports road fees that are paid directly by the road users, and the revenues from hard tolls are supposed to be sufficient to meet all the private sector's payment needs. On the other hand, the shadow tolls are either paid fully or subsidised by the government based on the user demand, facility availability and performance of the contractor. A number of countries, such as, Spain, UK, and Portugal link shallow tolls to a combination of the three aforementioned standards (Perkins 2013; Organisation for Economic Co-operation and Development-OECD 2008).

User demand fees are paid based on the traffic volume (Brown et al. 2009). While availability payments depend on the lane availability, asset safety features, road surface quality, vehicle class, and vehicle journey time reliability; performance payments are based on timely maintenance works, adequate safety and traffic flow control measures, and proactive response to accidents and weather vagaries (Perkins 2013; Burke \& Demirag 2015). Whereas, Rothballer \& Kim (2013) argues that majority of the citizens and politicians hate tolls, on the contrary, for example, the toll revenue on the Indiana toll road in the USA doubled after being upgraded and turned into a PPP in 2006 (Engel, Fischer \& Galetovic 2009).

Something that is emerging, though not a universal condition for toll revenue generation is ancillary revenues. 
As is the practice on most of India's expressways, ancillary revenues not only act as viability enhancement schemes for PPP projects to the private sector, but also an innovative mechanism of supplementing revenues from road tolls for government (Asian Development Bank 2015). Rothballer \& Kim (2013) identified three ways through which ancillary revenues can be generated. First is the continuous receipt of funding from businesses such as retail outlets, advertising, accommodation, cross-selling, renting out space for fibre-optic cables along the highway, service stations, restaurants, and utility corridors. Second is the buying of land before publicly announcing a PPP project, and later selling it at incremental prices or leasing it to real estate developers as project activities commence. The last one is where government subjects an added annual property tax levy to all the land within a certain distance of the enhanced or developed facility.

Finally, Tsukada (2009) and Rothballer \& Kim (2013) suggest key strategies for designing an effective toll fees structure and enforcement process to include:

$>$ Ensuring that newly constructed or upgraded facilities improve the quality of service, and the value added therefrom is appropriately communicated to the citizens;

$>$ Instituting differentiated toll rates by adjusting charges according to time, location, usage, and vehicle category;

$>$ Using payment mechanisms that maximize productivity, but remain accessible to all users. For instance, as e-tolls are introduced, manual payment systems should continue to be used in order to meet the interests of the poor and those that are less adaptable to electronic systems;

$>$ Implementing effective payment procedures by having relevant legislation, competent and professional enforcement teams, and taking necessary precautions to detect illegal usage;

$>$ Mitigating the adverse social consequences of user charges by providing alternative infrastructure facilities, and reduced tariffs for vulnerable parties and groups at risk;

$>$ Concession agreements should provide for potential inflation by linking the level of tolls to either consumer price index or wholesale price index.

\subsection{Tolling as an instrument for transport demand management}

Although road user tolls provide financing for fast-tracking road infrastructure development, they are, however, capable of diverting traffic volume to toll free parallel roads, which are usually of inferior quality, low speed, less safe and located in areas that are more sensitive to air and noise pollution (Kelleher 2014; Rothballer \& Kim 2013). Other factors notwithstanding, the low appetite for toll roads is normally caused by the enforcement of prohibitive road user charges, as was the case around 2005 after the government of Japan had almost doubled road toll fees (See, OECD 2008). Similarly, in the recent past, the residents of Bulawayo in Zimbabwe sued the government over introduction of toll fees on Victoria Falls road, because they had never been consulted nor provided with alternative free to use routes (Mbara, Nyarirangwe \& Mukwashi 2010).

According to Perkins (2013) on average traffic volumes fall short by $45 \%$ against projections in the first year of operation on toll roads in Australia. Although traffic volume is difficult to forecast with accuracy, government has an upper hand over the private sector in such matters, since it largely controls town planning and land use decisions, and provision of alternative toll free roads or suppression of competing services (Chung, 2008). Perkins (2013) noted that expected traffic volumes on toll roads can be realized when demand risks have been well identified, understood, analysed, assessed and managed; and such must be emphasised throughout the project processes (Rothballer \& Kim 2013).

Relatedly, OECD (2008) singles out the implementation of a flexible toll fee-charging scheme as one of the best ways towards improving the demand for toll roads. For instance, a 50\% toll discount increased traffic volume in Aganogawa and Hitachi cities in 2003 in Japan to about 195\% and 170\% on weekends/national holidays and weekdays respectively. While in Portugal, local residents living within close proximity of the tolled sections of the roads are allowed 10 free trips and a 15\% discount on subsequent travels (Ricardo-AEA 2014). Similarly, in South Africa, residents living near tolled road sections without alternative travel options are offered toll discounts (Rothballer \& Kim 2013).

\subsection{Country specific road tolling practices}

While tolling applies to both PPP and non-PPP roads, in this study the discussion is about PPP toll roads. Globally, countries have had slightly varying PPP road tolling histories. As such, this study draws lessons from PPP road tolling experiences of countries from different continents. These include the UK and Portugal representing Europe, South Africa for Africa, India for Asia, and the USA for North America.

4.3.1 South Africa's tolling practices

The road toll revenue contributions are only based on the "user pay principle", and toll roads are supposed to have alternative routes (South African National Roads Agency Ltd-SANRAL Declaration of Intent 2005-2008; Tolmie 2014), though the alternative routes need not be of the same standard as toll roads (Persad, Walton \& Wilke 2005). SANRAL is mandated to regulate and differ tolling practices based on the vehicle classification, toll road section, 
human status, and the toll collection system. Three toll collection systems of traditional, electronic, and open road tolling are being employed, and in particular a congestion charge zone through transport online platforms are being used in some cities to provide real time information on the flow of traffic (Matsiliza 2016). Among other tolling practices enforced by SANRAL include; setting standard toll tariffs, discounts and exemptions, and adjusting tariffs annually based on the consumer price index.

Toll discounts are provided throughout the week, but vary based on the time of the day and day of the week, public holiday, and the vehicle class. However, these discounts are only awarded on condition that toll payments have been effected within the 30 days of the invoice issue (SANRAL adjusted toll tariffs schedule 2017). While toll exemptions are limited to vehicles; providing public transport and emergency services, adapted for use by persons with disabilities, and for specific inter and non-governmental organisations (Republic of South Africa 2016). However, beneficiaries to discounts and exemptions must fully comply with the corresponding regulations of South Africa.

\subsubsection{Portugal's tolling practices}

Portugal uses real and shadow tolls to generate revenues for PPP projects. By 2009 , the country had $55 \%, 37 \%$, and $8 \%$ of the roads applying real tolls, shadow tolls and free of usage respectively. In fact, the PPP non-tolled roads are often connector roads, which are built by the concessionaire as part of the contract requirement. Portugal relies on both traditional and electronic systems for toll collection, though new roads being constructed now only use electronic systems.

Where the traffic volumes are projected to exceed 15,000 vehicles per day, real tolls are used and the concessionaire may be allowed to employ congestion pricing schemes; and, where the traffic volumes are projected to be below 10,000 vehicles per day, shadow tolls are the most preferred. Though with modest traffic volume expectations, a combination of real tolls, and shadow tolls are used. However, the government is considering removing shadow tolls from highways where the real tolls have become sufficient in meeting project financial requirements, especially on urban commuter routes.

Source: Brown et al. (2009)

4.3.3 United Kingdom's tolling practices

Most of the motorways in the United Kingdom use shadow tolls (based on traffic volumes, service and asset availability, and performance) payment mechanisms than real tolls to secure private sector financing (OECD 2008; Brown et al. 2009). In terms of PPP models, UK PPP motorways use more of DBFO and less of BOT arrangements. 4.3.4 United States of America's tolling practices

Toll rate setting varies between States. In some States, public entities directly control toll rates, in others its contract provisions that determine toll rates, and some provide the maximum rate beyond which toll rates cannot be increased. For instance, the rate of return on investment and the consumer price index in Minnesota and Florida respectively are toll provisions that require toll increases to be built in contracts. In a few States, the toll charges are supposed to be removed from PPP toll roads, the moment the acquired loan (debt) to develop such facilities has been fully paid.

Majority of the PPP agreements include rate of return caps to ensure that the private firms do not make abnormal profits at the expense of roadway maintenance, construction quality or reasonable user fees, and any revenues made beyond the cap has to be remitted to the state highway fund (Federal Highway Administration 1992). Tolls collection means range from traditional tollbooths to video-based systems, and most States apply the DBFOM PPP model but with several variants (U.S. DOT 2016).

Across the States, the clauses of "comparable non-toll" and "non-compete" routes are common in PPP policies/contracts. While a few States promote having "comparable non-toll routes", majority allow the application of "non-compete routes". However, States that do not accept "non-compete" clause, adopt the "compensation clause" to compensate investors that receive reduced revenues due to alternative routes developed.

Source: Iseki, Eckert, Uchida, Dunn \& Taylor (2009), U.S. DOT (2016) and Baxandall, Wohlschlegel \& Dutzik (2009).

4.3.5 India's tolling practices

Tolled highways that depend on real toll fees are meant to apply the BOT (Toll) model. Unless such projects become non-viable during implementation or receive poor response from the private sector, and are turned into BOT (annuity) projects. However, from 2012 the response rate for both BOT (toll) and BOT (annuity) has been poor that the government has had to shift many projects to the Engineering procurement construction model. The main features of the toll policy include;

* Uniform user fees rates (subject to annual review and inflation adjustments) are charged on most national highways, and the tolls payable are based on per kilometre of travel and the class of vehicle used;

* Discounted user charges depend on the multiple journeys made in a day/month, and local residents that make short journeys are entitled to a steep discount compared to residents;

* For toll fees exempt vehicles, a 10\% capital support is paid to the concessionaire as compensation. Across the country, PPP toll projects qualify for a maximum of $40 \%$ financial support from the viability gap fund 
scheme.

Source: Asian Development Bank (2015) and Haldea (2013).

\section{Country specific public private partnership road experiences}

Road cases are drawn from four continents. Africa is represented by Nigeria, South Africa and Mozambique; Europe by Croatia and Norway; North America by Canada and Virginia; and Asia by India.

\subsection{The Lagos-Ibadan Expressway project in Nigeria}

In 2009 the government contracted a private company for 25 years, to reconstruct, expand and maintain the 110 Km Lagos-Ibadan Expressway at an estimated cost of 89.53 billion naira under BOT arrangement (Iloh \& Bahir 2013). The concessionaire was expected to complete the construction works in the first four years, and later use 21 years to maintain the facility and collect tolls from the road users, in order to recover investment costs and realize returns. Key project assignments included increasing the road carriageways from four to between six and ten lanes, construction of parking areas especially for heavy-duty vehicles and rest areas for convenience, and provision of emergency communication equipment for the welfare and security of highway users (Iloh \& Bahir 2013).

Unfortunately, because the concessionaire never secured funding to execute construction works on time, in 2012 the government terminated the contract (Oluwasanmi \& Ogidi 2014), and subsequently contracted new two private companies to continue with the project. On the other hand, the public sector also failed to competently execute its mandate. Babatunde et al. (2013) attributed project failure to: inadequate PPP knowledge, skills and capacity from both private and public sector players; failure to engage external technical advisers; poor evaluation, monitoring and due diligence by government; use of non-competitive bidding; signing of contract without designs and evidence of financing; failure by the concessionaire to access credit from local and international banks; land acquisition difficulties; poor risk allocation among the parties; and the politicization of the concession.

\subsection{The Lekki Expressway project in Nigeria}

In 2006, a 30 year BOT contract between the Lagos state government and Lekki Concession Company to expand and upgrade $49.5 \mathrm{~km}$ road was signed, and in 2008 the construction of $20 \mathrm{~km}$ of a new coastal road was added to the contract (Babatunde et al. 2014). The project was estimated to cost US\$450 million, and the largest financial contribution was to come from the private sector. The private companies were to receive returns on investment through direct user toll collections, and the user toll rates had been estimated to range between 1-2 US dollars depending on the vehicle category (Babatunde et al. 2014).

The Lekki Expressway project has revamped transport services with outcomes such as improved security, road lighting, breakdown assistance, ambulance, customer call center, and a reduction in travel time from about 2 hours to 45 minutes (Kenny \& Lavanchy 2013). In addition, the project created over 635 temporary and 1146 longterm jobs, provided improved flora along the road with green belts, and led to the development of free Zones, a Hydrocarbon Park, a Deep Seaport and a future International Airport (Osei-Kyei et al. 2016; Kenny \& Lavanchy 2013).

Many factors contributed to the project successes. First, there was commitment from government to the project, evidenced by the provision of about US $\$ 42$ million mezzanine loan by the Lagos state Government (Babatunde et al. 2014), and land titles and rights which were timely issued and granted to the concessionaire to avoid any construction delays (Osei-Kyei et al. 2016). Second, the project involved more of the local content in both construction and local financial investments, as well as projects risks management (that led to more citizen support). Third, the financing agencies provided better lending terms to the project. For instance, Standard Bank extended "a 15 years loan of 2 billion naira in local currency at a fixed interest rate of $13.9 \%$ and also exempted the concessionaire from principal repayments for four years" (Wamwere 2016).

On the other hand, the project has had two main setbacks. Firstly, the charging of direct user fees has been criticised by human rights activists, and resisted by local residents and other road users to the extent that protests and court cases have been on the rise. For instance, when the concessionaire was planning to construct three tollgates within a distance of $5 \mathrm{Km}$, this was strongly fought by the public, and this forced government to provide alternative roads (Oluwasanmi \& Ogidi 2014; Amadi, Carrillo \& Tuuli 2014), even when the national laws never catered for such (Solicitor 2012). Still due to protests against direct user tolls, the government introduced shadow tolls in 2010, which though proved unsustainable that by 2013 a return to direct user tolls was made (Osei-Kyei et al. 2016). Subsequently, the government had to acquire the project concession rights through buyback arrangements at an expensive cost of N25.3 billion (U-Dominic et al. 2015). Secondly, the public complained of gross corruption due to contracting the concessionaire through direct negotiation processes without clear justification (Oluwasanmi \& Ogidi 2014).

With the foregoing, the project challenges arose due to: the devaluation of Nigeria's currency which shot up inflation to $35.2 \%$ from 2008-2013, and the concessionaire being given powers to increase toll fees without 
consulting government as long as the revisions were inflation based (U-Dominic et al., 2015); hurried and unpopular project decisions by government; and weak ways of integrating the public into project activities; lack of competitive and transparent tendering process; poor planning and unrealistic project costs; and negative public perception about direct user tolls (Osei-Kyei \& Chan 2016).

\subsection{The N4 Road project in South Africa and Mozambique}

Using an open and competitive tendering process, in 1997 the Trans African Concession company was contracted under a 30 years BOT model to finance, design, construct, rehabilitate, operate and maintain a 630 Km (N4 Toll road) at an estimated cost of R3 billion (Osei-Kyei \& Chan 2016; Taylor 2000). The contract was between the governments of South Africa and Mozambique on one hand, and the Trans African Concession consortium on the other. The concessionaire was expected to complete construction in three and half years at an estimated cost of R1.5 billion (PPIAF 2009; Taylor 2000), and thereafter collect tolls direct from the users in order to generate returns on investment and also operate and maintain the road facility. It was entirely the responsibility of the concessionaire to mobilise funds both in equity and debt to facilitate the construction phase of the project.

In the original contract, the N4 toll road network was running from Johannesburg to Maputo, however, in 2004 the contract was amended to include the distance between Pretoria and Witbank on the development grid (PPIAF 2009). The undertaking of the N4 road project was purposely to foster economic activities between the two Republics.

Notwithstanding a few weaknesses, the N4 toll road is the most successful cross boarder and inner country PPP road project in SSA. Osei-Kyei \& Chan (2016) mention that the project kept complaints from road users and local residents at minimum, created jobs for locals, was delivered on time, received positive customer responses about road quality, and improved economic trade and cooperation between South Africa and Mozambique. To Taylor (2000) the project reduced the travel distance and time by $150 \mathrm{Km}$, and approximately four hours respectively. Similarly, the road was upgraded to a four and a two lane separated carriageway with lanes wide enough (PPIAF 2009). The traffic demand grows at 5-7\% for passenger vehicles and $10 \%$ for freight per annum; and the concessionaire provides standby response teams to deal with incidents, is committed to continuous maintenance and upgrading, and provides the safest infrastructure facilities using the latest technology (Bhandari 2011).

Osei-Kyei \& Chan (2016) attribute project success to the: use of companies that had expertise and knowledge in delivering construction projects within a local context; tendering of projects through transparent and competitive processes; appropriate risk allocations and agreements; application of innovative approaches to overcome traffic congestions; provision of discounts to commuters and local residents; constant public consultations on toll increments; existence of a 24 hour road user help line and security surveillance service; government guaranteed the concessionaire's debt and equity; close cooperation between the two countries; and the cordial relationship between successive governments and the concessionaire. Furthermore, the PPIAF (2009) argues that the N4 project was successful because:

$>$ South Africa already had experience in PPP toll road projects;

$>$ the corridor between Pretoria, Johannesburg and Maputo had an established non PPP route well before the project initiation;

$>$ South African high toll revenue collections subsidise Mozambican low revenue collections;

$>\quad$ an efficient axle load control system exists along the corridor minimises road damage that would come from overloading of trucks, and;

$>$ Gauteng and Maputo are major economic trade centres for South Africa and Mozambique respectively, and at the same time the Maputo port works as an alternative exportation port to Durban for South Africa.

Though the N4 project sets the scene for self-reliance by African countries when investing in transport infrastructure, it had some implementation challenges. To some extent the project economically favoured South Africa over Mozambique. In fact, all the project investment firms were South African companies, except for one foreign company (Farlam 2005; Taylor 2000; PPIAF 2009). Furthermore, there was difficulty in harmonising dissimilar laws, taxation systems and currencies of the two countries (See, Wamwere 2016), and Mozambique in particular, lacked a well-established PPP legal and institutional framework (Taylor 2000).

Finally, PPIAF (2009) argues that the project only benefited only big companies because small firms had no capacity for such investment projects. However, the concessionaires were at a great risk since actual traffic volumes fell below the revenue expectations, yet subsidies for such eventualities had not been provided for (PPIAF 2009). This emanated from the unwillingness to pay tolls on a previously free of usage road, and widespread poverty in South Africa and Mozambique respectively (Taylor 2000). Corruption allegations, especially during toll fees collection also emerged, though camera systems were later installed to detect fraudulent practice (Osei-Kyei \& Chan 2016). 


\subsection{The 149 Capital Beltway project in Virginia}

Before the 2005 PPP agreement which allowed a private company to add four High Occupancy Toll (HOT) lanes, the 149 Capital Beltway had 8 General Use lanes that were free of usage. Whereas the eight general use lanes were to remain free of usage, the four HOT lanes were subjected to user fees upon construction. The 4 HOT lanes were aligned to the 8 General Use lanes in the distribution of a 4-2-2-4 lane configuration, and the private contractor was allowed to collect toll fees for 80 years.

Emerging lessons from the 149 Capital Beltway PPP contract are: Buses, vans and cars with more than two passengers, and emergency vehicles were not supposed to pay tolls; and vehicles with less than three passengers on board were to pay user fees (based on the number of passengers in a vehicle, the congestion levels, and the time of the day); while trucks were prohibited from using the HOT lanes. Also, the PPP agreement had serious lapses, in that, until the contract amendments of 2007, the 2005 agreement never provided for handover and maintenance requirements.

Source: Modified from Persad et al. (2005).

\subsection{The ETR Highway project in Canada}

Between 1993 and 1997, the province of Ontario constructed the ETR 407 a 68-mile electronic open-access road under the DBO model with the purpose of decongesting Highway 401. The private company was thereafter expected to operate and collect toll revenues from road users for 35 years, to essentially enable government to recover the US\$1.6 billion bond fund it had used to construct the road. However, after 18 months of operation, the government leased the road to a private company to finance, operate, manage, maintain, rehabilitate and collect tolls for 99 years. The lessee was obliged to comply with all the road safety standards set by the provincial government, and the official government vehicles were exempted from payment of tolls.

The road lease agreement introduced the congestion relief and expansion clauses to control traffic and revenue generation. The congestion relief clause allowed the lessee to increase toll rates, though the government would be entitled to some revenue payment upon increasing tolls fees beyond $2 \%$; and with the expansion clause, both the contract and the road designs provided for the expansion of the road. Also, laws assured the investor's revenue gains by denying road toll fees defaulters license plate renewals.

Notwithstanding the seemingly stringent measures, the project became unpopular a few years into operations. For example, litigation cases from a new government (the labour party) against tolls, congestion fees, and the conditioning of license plate renewals on toll payment were on an increase. The public opposed toll rate increases (e.g. the lessee increased tolls by $200 \%$ at peak hours shortly after lease signing). The highway failed to substantially reduce traffic congestion on the 401 road. Finally, the contract gave the lessee powers to increase tolls without seeking government approval, and the 99 year lease contract provided a too long a time to be in the hands of a single consortium.

Source: United Nations Economic Commission for Europe (2012), and Persad, Walton \& Wilke (2005).

\subsection{The East Coast Road (ECR) project in India}

In 2000 the Government of Tamil Nadu contracted a private Company for 30 years (excluding one year for construction) to rehabilitate, improve, maintain, operate and transfer a $113.2 \mathrm{Km}$ of the ECR at a cost of 600 million rupees (Rs), revert the management of the road facility to government after expiry of the operation period. The services under the operation phase included highway patrolling, ambulance services, breakdown tow-away service, and emergency call boxes.

Setbacks to the project included: Political pressure against implementing the $8 \%$ annual toll increments provided for in the concession. A ban on sand quarrying from a river bed situated along the project which led to a stoppage in the movement of sand bearing trucks on the road, yet these trucks were projected to contribute a third of the revenue. Monthly discounts for State Transport Corporation buses were surpassed by $70-80 \%$ as discount rates had not been linked to the number of trips per day, yet each bus made multiple trips a day. Construction inconveniences occurred due to the geometric design of the road which had several curves. In addition, 167 families were displaced from 12.5 acres of land, and about 851 trees cut during the road upgrades. However, as a compensation mechanism for the lost vegetation, a contract provision for planting 10,000 trees was made.

Regardless of the hindrances, the project has made remarkable progress: For instance, traffic has been growing at about 11\%; the road was constructed within the estimated cost and time; areas surrounding the ECR have had an increase in industrial and commercial investment; profits were realized a few years after the start of the operations phase; and over time the project has been experiencing a steady increase in revenues.

Factors that prompted project success included the government: provided detailed inspection schedules for assessing the contractor's regular maintenance performance; ensured law and order was maintained; provided financial support throughout the project life; and ensured that land acquisitions, issuance of approvals, and toll collection notifications were done on time. In favour of the contractor, the contract; prohibited constructing a new competing road or operating a parallel old road on a commercial basis; allowed at the concessionaire's request 
contract extension up to three years until the projected investment return is realised; and government must provide a $20 \%$ return guarantee on the outstanding cost of the project. From a finance viewpoint, the project used conventional corporate financing to avoid substantial legal fees and costs of incorporating a new company (i.e. SPV), and such provides the concessionaire the flexibility to mobilize revenue during financial distress. As well, the funds raised by the company were predominantly utilized for this project, because the ECR project was the only major project for the concessionaire at the time.

Given that ECR was an upgrade project, minimal construction risks were encountered since no complex under-passes, over-bridges and interchanges needed to be constructed; and public protests were minimised because only a few inhabitants were environmentally affected or displaced, and frequent road users and vehicles for bona fide locals living along the ECR were given toll discounts. Finally, the Highways Act of 2001 encourages quick disposition of land acquisition litigation cases, and also gives the government more powers to easily evict road reserve encroachers.

Source: Rajan, Siddharth \& Mukund (2010).

\subsection{The Istrian Y Toll motorway project in Croatia}

Istrian Y toll motorway is a $145 \mathrm{Km}$ single and two-lane dual carriageway, with differing toll charges for passenger vehicles ranging between Euro 1.90 and 3.70 depending on the road section used. In 1995, the government contracted a private company for 32 years to reconstruct the motorway under a DBFMO model. This is a four phased project, and after the completion of the first phase in 1999, the concessionaire had 28 years of toll collection, and return the road facility to the government at no cost.

Project achievements include: Increase in the real estate demand due to improved road network to the major cities. Development of tourism due to the discovery of archaeological sites during the construction works. Increase in toll revenues because of growth in the passenger vehicles. Installation of innovative and high quality construction solutions (e.g. road overpasses, underpasses, viaducts, bridges and intersections). Travel distance and time on the Mirna Bridge were reduced to $29.7 \mathrm{Km}$ and 71.2 minutes respectively; a substantial financial contribution has already been made by both the public and private sector partners; and the project design caters for the future expansion and upgrades of the motorway.

The achievements are attributed to two viewpoints. The first being the need to ensure that the concessionaire remains financially sound until the end of the project. For instance, the contract gives the concessionaire rights to start collecting tolls the moment the construction of each project phase has been completed. The government is required to compensate the concessionaire with the difference at a fall in the annual toll revenue targets. The concessionaire was exempted from income tax and other road taxes for 14 years; and Value added tax is exempted on toll revenues and refunded on construction materials.

The second view point is the project provided effective risk management measures. For instance, the concessionaire was required to acquire all the necessary permits before construction works. The concessionaire would be selected through an open international tendering process. The government and concessionaire were entitled to a $30 \%$ and $70 \%$ share of excess profits from the project revenues respectively. Project design approval, setting toll rates, land acquisition and transfer were the responsibility of government. On the other hand, the concessionaire was responsible for collecting tolls from users, and has the right to cancel the contract on severe regulatory risks or if the public partner never makes its financial contribution within four months. Though, the concessionaire would lose $12.5 \%$ of the construction price upon failure to complete a project phase on time. Generally, the contract price is expected to remain fixed, except for cost overruns approved by the public partner. However, the project fell short of the intended objectives. For instance, investment, maintenance and operation costs increased due to high passenger traffic volumes that were above the carrying capacity of the road, and low toll revenues as the number of freight trucks were far below the projections. Finally, the last two phases of the project never had specific start and completion dates, since the condition for their construction was that the traffic intensity needed to average 10,000 and 16,000 per day overall and in summer respectively.

Source: Bjørberg, Kristiansen, Graham, and Salaj (2015).

\subsection{The E-39 Highway project in Norway}

The project covers $22 \mathrm{kms}$, and $5 \mathrm{Kms}$ for new (with $10 \mathrm{kms}$ of tunnels \& 12 bridges) and old roads construction and improvement respectively, and was deemed to address the sharp corners, poor visibility and high traffic on the old road. As such, in 2003 the government contracted a SPV company for 27 years through a BOT model (after an open national bidding process) with the first 2 and the last 25 years for construction and operation phases respectively.

The road was opened for use immediately after completion of road construction in 2005, and the concessionaire collected toll revenues on behalf of the Norwegian Roads agency. The road agency makes annual payments to the concessionaire based on the facility availability and provision of quality services. Facility availability payments were conditioned on road designs and constructions producing less maintenances, and 
maintenance schedules that neither affected busy times nor caused congestion. Service quality (for operation and maintenance) payment were based on the cleanliness of the road and surrounding areas, road surface tests, lighting of the road, the quality of the air and safety systems, and time taken to replace broken assets (e.g. traffic signs). Also, the concessionaire was entitled to bonus and compensation payments for improved safety performance (e.g. reduction in accidents), and wear and tear of the road (if the heavy goods vehicles exceed the contract traffic forecasts) respectively.

Regarding risk allocation, the private company would own; costs of compliance to changes in general legislation and statutory requirements; cost overruns for operations, maintenance and service specifications; damage to infrastructure; latent defects on the road; and adverse weather conditions. On the other hand, the public partner was responsible for traffic and force majeure risks. However, latent defects beyond the contract time, regulatory and land acquisition risks required joint responsibility, and whoever caused project scope changes would incur the additional costs.

Source: Šeba (2015).

\section{Lessons for public private partnership emerging economies}

Lessons are being drawn from the already discussed PPP financing aspects, tolling practices and road project cases.

\subsection{Public private partnership financial management based on the 2008 global financial crisis}

The global financial crisis generally indicates how financial risks and their impacts can be mitigated to ensure sustainable PPP improvements. Whereas the public sector seems to absorb most of the consequences to the crises, it is noted that the private sector is capable of providing guarantees as well. As governments take a lead role in addressing crises challenges, they should never give leeway to imperfect market actors to play games against public interests.

Though Global financial crises sour financing conditions, PPP investment can still grow as long as the governments take formidable measures such as innovative financing, designing temporary schemes to respond to abrupt and rare shocks, and having both project and contract structures and legal and institutional frameworks that are strong and respected. Common measures that have been taken include abandoning projects, rebranding and redesigning projects, making marginal changes to existing projects, tightening value for money analysis and decision making processes, maintaining the status quo, actors taking up new responsibilities, and sharing of responsibilities through partnership arrangements (Greve \& Hodge 2013). Overall, the learning curve syndrome led countries to moderately handle the 2008 GFC better than its predecessors, the Asian and Dotcom bubble crises.

\subsection{Tolling practices and management}

Whereas tolling reduces traffic jams on previously congested routes, improves road safety and efficiency, and generates revenue for road infrastructure financing, on the other hand, poor forecasting of initial traffic and revenue performances, payment defaults, debt restructuring, delays to maintain and upgrade roads, opposition from special interest groups, and poor/lack of road toll history have been major hindrances to the success of PPP road projects (Mbara, Nyarirangwe \& Mukwashi 2010). Actually, most of the PPP road problems accrue from road usage payment fees. Regardless of the road tolling type, payments generally depend on each kilometre travelled per vehicle in line with the toll fees structure, which keeps changing over time in accordance with the set index formula. Specific to shadow tolls, as traffic volumes increase, lower payments are made by government (and the reverse is true), but no additional returns are offered to the concessionaire beyond the maximum traffic revenue limit, unless the contract stipulates otherwise. Different from shadow tolls, for hard tolls, any revenue collected above the predetermined minimum level has to be shared between the public and private sector organisations. However, where the revenue collected is below the projected minimum level, the government either increases user toll fees, lobbies for grants or provides subsidies. By a global observation, majority of the countries use the BOT roadtolling model, apart from a few countries that apply the DBFO model or a combination of the two.

Additionally, countries are migrating from manual/semi-manual to full automated tolling systems, however where a toll road is a general user facility, a combination of manual and electronic tolling systems are at large still being used to serve the differing paying interests of the various categories of users (Tsukada 2009). Direct user fees are more common than shadow tolls, the management of tolling practices is best placed with government, and ancillary facilities are a good mechanism of supplementing inadequate toll revenues. However, tolling roads without enough stakeholder engagements causes continuous protests, and globally there is great resistance against tolling previously free access roads. Therefore, effective demand risk indexing, providing quality road facilities and services, charging tolls on previously free roads only after substantial upgrades, consultation and involvement of the public when tolling road sections and introducing toll fees, transparency in all toll transactions, provision of alternative routes and modes of transport, and employing flexible toll charging schemes, have the potential to solve the low demand and unpopularity for PPP toll roads. 


\subsection{Common road projects experiences and practices}

Most PPP roads are largely brownfield projects executed through renovation and road upgrade arrangements, with road bypasses and extensions being constructed as new roads. Private and public partners usually sign BOT agreements, with contract durations averaging between 25 and 35 years. Out of the total contract period, the construction phase takes up 1-4 years. Whereas the financing of the construction phase is mainly the responsibility of the private sector (and at times with small contributions from government), the payment demands of the contractor for the construction works as well as the operation and maintenance of the road facilities are often cleared using revenues from direct user tolls.

Globally, the construction of roads through PPP arrangements has to some extent improved road quality and support services, reduced construction time and road congestions, created jobs, reduced travel time and distance, improved road safety, enhanced mushrooming of private businesses, and facilitated community development. Such PPP road achievements are attributed to: Short term scheduled payments that are conditioned on the availability and quality of infrastructure and services, periodic growth of direct user revenue collections, extending bonus payments to the contractors in case of reduced road accidents, compensating the concessionaire in case of an increase in traffic volume beyond traffic forecasts or providing subsidies in case of a reduction in projected road usage, minimised complaints from road users and locals, full commitment and goodwill of government for PPP projects, on time road maintenance and upgrades, and provision of road safety features.

On the other hand, most PPP road projects have had limited success, evidenced by project delays, premature contract termination, abrupt changes in contract terms and conditions, lack of project funding by the concessionaires, among others. Such have been escalated by enormous litigation cases, corruption, public protests against direct user tolls, low traffic volumes, poverty, selective tendering processes, poor planning and feasibility studies, unbalanced allocation of risks among partners, engaging incompetent project advisors, and the irregular designing and implementation of contracts.

Findings further indicate that; control of road traffic seems to succeed through expansion of existing roads and charging of congestion fees rather than constructing new parallel non-toll roads; compared to Greenfield projects, upgrading Brownfield roads greatly reduces costs and risks of delivering a road project; and where the costs for incorporating a new company are too high or where financial distress may be rumoured to occur in future, conventional financing is preferred to SPV financing. In addition, unless small firms are subcontracted/syndicate, they may for long remain disfavoured in PPP investment projects. As well, well-calculated discounts/exemptions, subsidies, contract period extensions, increase in toll rates or any other risk mitigation decisions should be made with the intention of avoiding project risk escalations, and governments should support the private sector to remain financially stable throughout the project.

Relatedly, lack of PPP country experience, missing PPP local content in both manpower and other resources, and lack of well-established or implemented legal and institutional systems for national projects, and harmonised legal, economic, social and political countries' agendas for cross border projects, are the main hindrances towards successful implementation of PPP road projects. Overall, the study establishes that the construction phase takes the shortest duration compared to other PPP project phases, and that PPPs in the developing world (especially Africa) are more challenging than in the developed world, and strong economies can more easily influence PPP investment growth in other economies than small economies can reciprocate. Finally, undertaking only a few PPP projects at a time encourages successful outcomes, and the reverse is true when a country executes several PPP projects concurrently.

\section{Conclusion}

The inadequacy and underdevelopment of road infrastructure and associated services in Africa requires critical rethinking in order to address their disturbing effects on the continent's socio-economic growth. This study proposes the public private partnership modality as an effective strategy to tackle the road infrastructure and services gaps as well their effects on national and continental development in Africa. Whereas both developed and developing countries have taken up PPPs for public investment, findings have however indicated that their level of adoption and success has been more in economically stable than with economically constrained nations.

In ensuring that PPPs work well for emerging economies, a discussion on financial challenges, tolling practices, and road experiences was done. Financial challenges were anchored on the GFC 2008 to establish its causes and impact on PPP projects, and how countries should have/responded to its negative impacts. Tolling focussed on the road tolling practices that various countries employ, and their contribution to revenue and transport demand. While the PPP road experiences emphasised the project successes and failures, and conditions for either situation. Finally, a synthesization of the global PPP financial challenges, tolling practices, and road experiences was conducted to come up with lessons that nascent and emerging PPP markets, especially African countries, can utilize for better road infrastructure development. 


\section{References}

Amadi, C., Carrillo, P. \& Tuuli, M. (2014). Stakeholder management in public private partnership projects in Nigeria: Towards a research agenda. AB Raiden \& E. Aboagye-Nimo (Eds.): 423-432.

Asian Development Bank. (2015). Trial Balance Private Sector Financing for Road Projects in India.

Babatunde, S.O., Perera, S., Udeaja, C. \& Zhou, L. (2014). Challenges of Implementing Infrastructure Megaprojects through Public-Private Partnerships in Nigeria: A Case Study of Road Infrastructure. International Journal of Architecture, Engineering and Construction, 3(2):142-154.

Baxandall, P., Wohlschlegel, K. \& Dutzik, T. (2009). Private roads, public costs: The facts about toll road privatization and how to protect the public.

Biau, C; Dahou, K. \& Homma, T. (2008). How to increase sound private investment in Africa's road infrastructure: Building on country successes and OECD policy tools. Expert Roundtable Investment in Transport Infrastructure. NEPAD \& OECD Africa Investment Initiative.

Bjørberg, S., Kristiansen, B.F., Graham, L., Salaj, A.T. (2015). COST Action TU1001 Public Private Partnerships in Transport: Trends \& Theory P3T3 2014 Discussion Papers Country Profiles \&Case Studies.

Brown, J.W., Pieplow, R., Driskell, R.L., Gaj, S.J., Garvin, M.J., Holbombe, D.L., Saunders, M.T., Seiders Jr, J.J. \& Smith, A.L. (2009). Public-private partnerships for highway infrastructure: Capitalizing on international experience (No. FHWA-PL-09-010).

Burger, P., Tyson, J., Karpowicz, I. \& Coelho, M.D. (2009). The effects of the financial crisis on public-private partnerships (Vol. 2144). International Monetary Fund.

Burke, R. \& Demirag, I. (2015). Changing perceptions on PPP games: Demand risk in Irish roads. Critical Perspectives on Accounting, 27:189-208.

Chung, D. (2008). Private Provision of Transport Infrastructure-Unveiling the Inconvenient Truth in New South Wales. In 31st Australasian Transport Research Forum, October (pp. 68-85).

Connolly, C \& Wall, T. (2011). The global financial crisis and UK PPPs. International Journal of public sector management, 24(6): 533-542.

Engel, E.M., Fischer, R.D. \& Galetovic, A. (2009). On the efficient provision of roads

EPEC, (2009). The financial crisis and the PPP market. Potential Remedial Actions (Abridged version, August 2009)

Ferrantino, M. (2009). Chapter Two-Synthesis and Implications of Findings: In Sub-Saharan Africa: Effects of Infrastructure Conditions on Export Competitiveness. Third Annual Report, Investigation No. 332-477, Publication 4071: U.S. International Trade Commission.

Haldea, G. (2013). Public private partnership in national highways: Indian perspective (No. 2013/11). OECD Publishing.

Iloh, J.O. and Bahir, M. 2013. Public Private Partnership (PPP) and Social Service Reform in Nigeria: 19992007. Journal of Educational and Social Research, 3(10):101-108.

Iseki, H., Eckert, J., Uchida, K., Dunn, R. and Taylor, B.D. 2009. Task B-2: Status of legislative settings to facilitate public private partnerships in the US. California PATH Program, Institute of Transportation Studies, University of California at Berkeley.

Jabara, C. (2009). Chapter One-Introduction and overview: In Sub-Saharan Africa: Effects of Infrastructure Conditions on Export Competitiveness. Third Annual Report, Investigation No. 332-477, Publication 4071: U.S. International Trade Commission.

Jennett, N. (2010). PPP and the Consequences of the Financial Crisis. Financing capacity and future perspectives. The European PPP Expertise Centre/OECD Conference Centre Paris, 12-13 April 2010.

Kelleher, C. (2014). Report on the State of the EU Road Haulage Market: Task B: Analyse the State of the European Road Haulage Market, Including an Evaluation of the Effectiveness of Controls and the Degree of Harmonisation.

Kenny, J. \& Lavanchy, R. 2013. Emerging Partnerships: Top 40 PPPs in emerging markets. IFC, PPIAF and Infrastructure Journal: 26-27.

Loxley, J. (2012). Public-private partnerships after the global financial crisis: Ideology trumping economic reality. Studies in Political Economy, 89(1): 7-38.

Mason, M. (2010). Sample Size and Saturation in PhD Studies using Qualitative Interviews [63 paragraphs]: Forum Qualitative Sozialforschung / Forum Qualitative Social Research, 11(3), Art. 8. [Online]. Available: http://nbn-resolving.de/urn:nbn:de:0114- fqs100387.

Matsiliza, N.S. (2016). Critical Factors in Respect of Managing the E-Toll Road Project in Gauteng, South Africa.

Mbara, T.C., Nyarirangwe, M. \& Mukwashi, T. (2010). Challenges of raising road maintenance funds in developing countries: An analysis of road tolling in Zimbabwe. Journal of Transport and Supply Chain Management, 4(1), pp.151-175.

OECD. (2008). Transport Infrastructure Investment: Options for Efficiency. OECD publishing

Oluwasanmi, O. \& Ogidi, O. (2014). Public private partnership and Nigerian economic growth: Problems and 
prospects. International Journal of Business and Social Science, 5(11):132-139

Ondiege, P., Moyo, J.M. \& Verdier-chouchane, A. (2013). Developing Africa's Infrastructure for Enhanced Competitiveness. The Africa Competitiveness Report 2013. 69-92.

Osei-Kyei, R. and Chan, A.P. (2016). Developing transport infrastructure in Sub-Saharan Africa through PublicPrivate Partnerships: Policy practice and implications. Transport Reviews, 36(2), pp.170-186.

Perkins, S. 2013. Better regulation of public-private partnership for transport infrastructure: Summary and conclusions. International Transport Forum Discussion Paper

Persad, K.R., Walton, C.M. \& Wilke, J. (2005). Alternatives to non-compete clauses in toll development agreements (No. FHWA/TX-07/0-5020-1).

Rajan A, T., Siddharth, R. \& Mukund, S.P. (2010). PPPs in road renovation and maintenance: a case study of the East Coast Road project. Journal of Financial Management of Property and Construction, 15(1), pp.21-40.

Reeves, E. \& Palcic, D. (2017). Getting back on track: the expanded use of PPPs in Ireland since the global financial crisis. Policy Studies, pp.1-17.

Republic Of South Africa. (2016). Gauteng Freeway Improvement Project, Toll Roads. Exemptions from the Payment of Toll. Government Gazette, 19 December 2016, No.40508.

Ricardo-AEA. (2014). Evaluation of the implementation and effects of EU infrastructure charging policy since 1995. Report for the European Commission. Ricardo- AEA/R/ED57769 Issue no.3.

Rothballer, C. \& Kim, H. (2013). Strategic Infrastructure Steps to Prepare and Accelerate Public-Private Partnerships. In World Economic Forum.

SANRAL adjusted toll tariffs schedule. (2017). Effective From $3^{\text {rd }}$ March 2017: www.nra.co.za > Home > About Tolls > Toll Tariffs \& Discounts.

SANRAL Annual Report. (2016). Annual report 2015/16. Registration number 1998/009584/30. Republic Of South Africa.

SANRAL Declaration of Intent 2005-2008. Creating wealth through infrastructure.

Šeba, M.G. (2015). COST Action TU1001 Public Private Partnerships in Transport: Trends \& Theory P3T3 2014 Discussion Papers Country Profiles \&Case Studies.

Solicitor, D.C. (2012). Nigeria PPP Review, 1(1):1-6.

Svigelj, M. \& Hrovatin, N. (2013). The Impact of the Financial and Economic Crisis on Public Private Partnerships. Mednarodna Revija za Javno Upravo, 11(2):77-91.

Tsukada, S. (2009). Global Experiences of Public Private Partnership for Highway Development.

U-Dominic, C.M., Ezeabasili, A.C.C., Okoro, B.U., Dim, N.U. \& Chikezie, G.C. (2015). A Review of Public Private Partnership on some Development Projects in Nigeria. International Journal of Application or Innovation in Engineering \& Management (IJAIEM), 4(3):64-75

United Nations Economic Commission for Europe (UNECE). 2012. Introduction to Public-private partnerships. Can public-private partnerships improve infrastructure and deliver better public services?

Wamwere, J.M. (2016). Infrastructure in Africa: Overcoming the Legal and Commercial Challenges to Successful Public Private Partnerships. Riara Law School, Kenya.

Wohl, I. (2009). Chapter Three-Land Transport: In Sub-Saharan Africa: Effects of Infrastructure Conditions on Export Competitiveness. Third Annual Report, Investigation No. 332-477, Publication 4071: U.S. International Trade Commission.

World Bank Group. (2016). The State Of PPPs Infrastructure Public-Private Partnerships in Emerging Markets \& Developing Economies 1991-2015. 